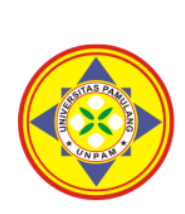
PERKUSS

\title{
PENGARUH KUALITAS PELAYANAN TERHADAP KEPUASAN KONSUMEN PADA PT PRINTEX JAYA SEMBADA DI SERPONG TANGERANG
}

\author{
Agung Tri Putranto \\ Universitas Pamulang, Tangerang Selatan, Banten, Indonesia \\ *dosen02047@unpam.ac.id
}

\begin{abstract}
Abstrak
Penelitian ini bertujuan untuk mengetahui pengaruh kualitas pelayanan terhadap kepuasan konsumen pada PT. Printex Jaya Sembada di Serpong Tangerang. Metode yang digunakan adalah explanatory research dengan sampel sebanyak 75 responden. Teknik analisis menggunakan analisis statistik dengan pengujian regresi, korelasi, determinasi dan uji hipotesis. Hasil penelitian ini variabel kualitas pelayanan diperoleh nilai rata-rata skor sebesar 3,007 dengan kriteria baik. Variabel kepuasan konsumen diperoleh nilai rata-rata skor sebesar 2,652 dengan kriteria baik. Kualitas pelayanan berpengaruh positif dan signifikan terhadap kepuasan konsumen dengan nilai persamaan regresi $Y=$ $10,525+0,532 \mathrm{X}$, dan nilai koefisien korelasi 0,651 atau memiliki tingkat hubungan yang kuat dengan nilai determinasi 42,4\%. Uji hipotesis diperoleh signifikansi 0,000<0,05.
\end{abstract}

Kata Kunci: Kualitas Pelayanan, Kepuasan Konsumen

\section{Abstract}

This study aims to determine the effect of service quality on customer satisfaction at PT. Printex Jaya Sembada in Serpong Tangerang. The method used is explanatory research with a sample of 75 respondents. The analysis technique uses statistical analysis with regression, correlation, determination and hypothesis testing. The results of this study variable service quality obtained an average score of 3,007 with good criteria. The consumer satisfaction variable obtained an average score of 2.652 with good criteria. Service quality has a positive and significant effect on customer satisfaction with the value of the regression equation $Y=10.525+0.532 X$, and the correlation coefficient value of 0.651 or has a strong relationship with a determination value of $42.4 \%$. Hypothesis testing obtained a significance of $0.000<0.05$.

Keywords: Service Quality, Consumer Satisfaction

\section{PENDAHULUAN}

Perkembangan zaman yang semakain maju maka tidak heran persaingan usaha semakin ketat ditambah kondisi perekonomian yang tidak menentu prilakuprilaku bisnis yang mempersiapkan diri dalam meningkatkan kemampuannya guna menghadapi berbagai tantangan di era globalisasi ini. Oleh karna itu secara khusus perusahaan harus meningkatkan pelayanan (service) baik secara mental kemampuan dan keterampilan untuk mencapai sasaran perusahaan.

Dalam khasus ini perusahaan yang bergerak dalam remanufacture tinta toner untuk printer $\mathrm{Hp}$ laserjet tidak hanya harus mempunyai produk yang unggul tetapi juga setiap pemimpin perusahaan harus dapat meningkatkan kualitas layanannya agar tingkat kepuasaan konsumen semakin meningkat dan akan memakai produk dan jasa perusahaan kita.

Produsen semakin menyadari akan arti penting pelayanan. Semakin perusahaan akan maju dan berkembang. Hal inilah yang disadari oleh para produsen maka dari itu dengan adanya perkembangan teknologi dan ilmu pengetahuan mereka berlomba untuk memberikan pelayanan yang terbaik bagi produsen dengan tujuan agar tetap eksis di dunia bisnis. Mereka berlomba memberikan fasilitas yang diinginkan oleh para konsumen dan berusaha mengetahui apa yang dibutuhkan konsumen yakni misalnya saja fasilitator yang biasa disebut dengan CRC (customer respond center). Dimana konsumen dapat meminta bantuan 
pelayanan dan sebagai media konsumen untuk menyampaikan ketidak puasannya maupun saran bagi perusahaannya untuk lebih maju lagi dalam memberikan pelayanan. CRC sebagai mediator harus dapat menjadi penengah bagi perusahaan untuk memberikan penetrasi dan perwakilan perusahaan untuk meminta maaf sebagai bentuk kurang maksimalnya dalam pelayanan kepada konsumen.

Keunggulan pelayanan didalam suatu perusahaan setidaknya dapat menjadi keberhasilan suatu perusahaan dalam menghadapi segala tantangan dan ancaman yang akan menghambat laju perkembangan perusahaan dimasa yang akan datang, mengingat betapa pentingnya peran kualitas pelayanan bagi kehidupan suatu perusahaan untuk meningkatkan potensi yang dimiliki, agar kualitas pelayanan tersebut dapat bersaing atau setidaknya mampu mengimbangi laju persaingan di dunia usaha.

Kualitas pelayanan ini sangat penting artinya bagi kehidupan suatu perusahaan, karena tanpa konsumen maka tidak akan terjadi transaksi jual beli diantara keduanya. Untuk itu kegiatan pelayanan perusahaan haruslah berorientasi kepada kepuasan konsumen. Kualitas pelayanan terhadap kepuasan konsumen dapat memberikan kontribusi pada perusahaan dalam meningkatkan pendapatan jangka panjangnya adalah pada sejauh mana kemampuan perusahaan melayani atau memberi pelayanan secara maksimal kepada para konsumennya secara sistematis dan terprogram yang tidak melanggar etika dalam sebuah bisnis.

Kualitas pelayanan menurut Endar Sugiarto (2012:36) adalah suatu tindakan yang dilakukan untuk memenuhi kebutuhan orang lain (konsumen, konsumen, klien, tamu dan lain-lain) yang tingkat pemuasannya hanya dapat dirahasiakan oleh orang yang melayani maupun yang dilayani. Kualitas pelayanan adalah suatu sikap atau cara dalam melayani konsumen supaya konsumen mendapatkan kepuasan yang meliputi kecepatan, ketepatan, keramahaan, dan kenyamanan.

Menurut Laksana (2013:60)

"Pelayanan adalah setiap tindakan atau kegiatan yang dapat di tawarkan kepada pihak lain, yang pada dasarnya tidak berwujud dan tidak mengakibatkan kepemilikan apapun". Melihat kondisi tersebut, pada saat ini para industri berusaha memberikan kualitas pelayanan yang baik untuk menarik konsumen, maka dari itu kunci sukses bagi perusahaan jasa adalah pelayanan jasa yang baik dan tersedianya produk jasa yang dibutuhkan konsumen juga peningkatan kualitas pelayanan baik

Pada perusahaan atau bisnis yang berorientasi pada konsumen, maka tidak dapat dihidari bahwa kualitas pelayanan menjadi satu-satunya faktor penentu dari eksitensi perusahaan yang lebih memberikan pelayanan yang memuaskan konsumennya.

Kepuasan konsumen bisa dilihat saat konsumen merasa puas apabila harapan mereka terpenuhi dan merasa apabila harapan mereka terlampui, konsumen yang puas cenderung akan loyal lebih lama, membeli banyak, kurang peka terhadap perubahan harga dan pembicaraanya menguntungkan perusahaan.

Kepuasan konsumen dapat menciptakan kesetiaan atau loyalitas konsumen kepada perusahaan yang memberikan pelayanan dan kualitas yang memuaskan, konsumen yang telah mencapai kepuasan sangat memungkinkan sekali untuk memungkinkan sekali untuk memberitahukan kepada teman, rekan maupun orang lain akan pengalaman yang mereka dapatkan tentang produk dan jasa perusahaan.

Menurut Philip Kotler yang dikutip oleh Rambat Lupiyoadi (2013:158)“ kepuasan merupakan tingkat perasaan dimana seseorang menyatakan hasil perbandingan atas kinerja produk atau jasa yang diterima dan diharapkan". PT. Printex Jaya Sembada Karawaci, berdiri pada tahun 2009 bertempat didaerah Ciputat Tangerang Selatan. Perusahaan ini merupakan salah satu perusahaan yang 
bergerak di bidang jasaisi ulangtinta serbuk untuk printer Hp laserjet (remanufaktur), serta memberikan jasa service box tinta (catridge) atau printer. Dengan memberikan pelayanan pengiriman barang (delivery order).

Di PT. Printex Jaya Sembada masih terdapat beberapa masalah yang menyebabkan konsumen merasa kurang puas dan akhirnya menyebabkan konsumen berfikir ulang untuk membeli kembali, seperti fasilitas komputer yang sering mengalami ganguan atau permasalahan. Serta permasalahan seperti pengiriman barang yang terkadang masih kurang memadai dan tenaga kerja untuk melayani konsumen sehingga memperlambat proses pelayanan dan penanganan kepentingan konsumen yang seharusnya bisa diproses dengan cepat dan tepat, karena tidak jarang konsumen yang membeli dan menyampaikan keluhannya tanpa harus menunggu yang menurut mereka hanya membuang waktu mereka. Demikian pula jumlah konsumen yang belum maksimal.

Adapun cara pelayanan terhadap konsumen masih belum dijalankan dengan baik, Masalah-masalah yang terdapat di perusahaan belum selesai sampai disitu. Tingkat kepedulian kepada konsumen masih belum tercipta, kurangnya penanganan dalam menangapi complain terhadap produk tinta terkadang masih kurang ditangapi dengan baik dan cepat, beberapa konsumen mengharapkan agar perusahaan memperhatikan dalam mencermati kepuasan konsumen sehingga perusahaan bisa lebih meningkatkan kualitas pelayanannya.

Selama ini evaluasi kinerja pemasaran yang dilakukan oleh perusahaan dengan maksud untuk mengevaluasi pencapaian yang diperoleh perusahaan termasuk didalamnya adalah untuk membangun kepuasan konsumen dalam rangka untuk menciptakan kepuasan konsumen. Disisi lain, persoalan timbul dimana penjualan yang dilakukan tidak selalu dapat memenuhi harapan manajemen, berikut ini realisasi hasil penjualan dan target yang ditetapkan oleh perusahaan.

Mengacu pada pemasaran yang merupakan fungsi bisnis yang berhubungan dengan konsumen namun disisi lain justru yang terjadi diperusahaan banyak yang kontradiktif antara pelayanan dengan tingkat persepsi konsumen menjadikan dasar pertimbangan kajian penelitian ini. Oleh karena pemasaran merupakan proses memperlajari kebutuhan dan keinginan konsumen, dan memuaskan konsumendengan produk dan pelayanan yang berkualitas dan pada takaran mampu bersaing dengan kompetitif, maka dalam penelitian ini penulis memilih PT. Printex Jaya Sembada yang paling strategis yang di anggap mempunyai indikator dibidang pelayanan untuk kepuasan konsumen.

Berdasarkan uraian di atas penulis tertarik untuk mengadakan penelitian dengan mengambil judul "Pengaruh Kualitas Pelayanan Terhadap Kepuasan Konsumen pada PT. Printex Jaya Sembada di Serpong Tangerang".

\section{TINJAUAN PUSTAKA}

1. Kualitas Pelayanan

Menurut Kotler dalam Tjiptono (2019:59) menyatakan bahwa “Kualitas pelayanan adalah tingkat keunggulan yang diharapkan dan pengendalian atas tingkat keunggulan tersebut untuk memenuhi keinginan konsumen".

\section{Kepuasan Konsumen}

Menurut Kotler dan Keller (2019:138), “Kepuasan merupakan perasaan seseorang akan kesenangan atau kekecewaan setelah membandingkan kinerja suatu produk yang dirasakan dengan harapan mereka. Jika kinerja tidak memenuhi harapan, konsumen tidak puas dan jika kinerja sesuai dengan harapan maka konsumen puas".

\section{METODE}

\section{Populasi}

Yang dijadikan sebagai populasi dalam penelitian ini adalah responden yang berjumlah 75 responden PT. Printex 
Jaya Sembada di Serpong Tangerang

2. Sampel

Teknik pengambilan sampling dalam penelitian ini adalah sampel jenuh, dimana semua anggota populasi dijadikan sebagai sampel. Dengan demikian sampel dalam penelitian ini sampel yang digunakan berjumlah 75 responden.

\section{Jenis Penelitian}

Jenis penelitian yang dipakai adalah asosiatif, dimana tujuannya adalah untuk mengetahui atau mencari keterhubungan antara variabel independen terhadap variabel dependennya
4. Metode Analisis Data

Dalam menganalisis data digunakan uji validitas, uji reliabilitas, analisis regresi linier sederhana, analisis koefisien korelasi, analisis koefisien determinasi dan pengujian hipotesis.

\section{HASIL DAN PEMBAHASAN}

\section{Analisis Deskriptif}

Pada pengujian ini digunakan untuk mengetahui skor minimum dan maksimum skor tertinggi, ratting score dan standar deviasi dari masing-masing variabel. Adapun hasilnya sebagai berikut:

Tabel 1. Hasil Analisis Descriptive Statistics

Descriptive Statistics

\begin{tabular}{lr|r|r|r|r} 
& N & Minimum & Maximum & Mean & Std. Deviation \\
\hline Kualitas pelayanan $(\mathrm{X})$ & 75 & 25 & 39 & 30.07 & 3.504 \\
\hline Kepuasan konsumen $(\mathrm{Y})$ & 75 & 20 & 34 & 26.52 & 2.863 \\
\hline Valid N (listwise) & 75 & & & & \\
\hline
\end{tabular}

Kualitas pelayanan diperoleh varians minimum sebesar 25 dan varians maximum 39 dengan ratting score sebesar 3,007 dengan standar deviasi 3,504. Skor ini termasuk pada rentang sakala 3,40 4,19 dengan kriteria baik atau setuju. Kepuasan konsumen diperoleh varians minimum sebesar 20 dan varians maximum 34 dengan ratting score sebesar 2,652 dengan standar deviasi 2,652. Skor ini termasuk pada rentang sakala 3,40 4,19 dengan kriteria baik atau setuju.

\section{Analisis Kuantitatif}

Pada analisis ini dimaksudkan untuk mengetahui pengaruh variabel independen terhadap variabel dependen. Adapun hasil pengujian sebagai berikut:

\section{a. Analisis Regresi Linier Sederhana}

Uji regresi ini dimaksudkan untuk mengetahui perubahan variabel dependen jika variabel independen mengalami perubahan. Adapun hasil pengujiannya sebagai berikut:

Tabel 2. Hasil Pengujian Regresi Linier Sederhana Coefficients ${ }^{a}$

Unstandardized Standardized Coefficients Coefficients

\begin{tabular}{l|r|r|r|r|r} 
Model & \multicolumn{1}{c}{ B } & Std. Error & Beta & $t$ & \multicolumn{1}{c}{ Sig. } \\
\hline 1 (Constant) & 10.525 & 2.197 & & 4.790 & .000 \\
\hline Kualitas pelayanan $(\mathrm{X})$ & .532 & .073 & .651 & 7.328 & .000 \\
\hline
\end{tabular}

Berdasarkan hasil pengujian
pada tabel di atas, diperoleh
persamaan regresi $Y=10,525+$
$0,532 X$. Dari persamaan tersebut
dijelaskan sebagai berikut:
1) Konstanta sebesar 10,525 diartikan
jika kualitas pelayanan tidak ada,
maka telah terdapat nilai

Berdasarkan hasil pengujian pada tabel di atas, diperoleh persamaan regresi $\mathrm{Y}=10,525+$ 0,532X. Dari persamaan tersebut dijelaskan sebagai berikut:

Konstanta sebesar 10,525 diartikan maka telah terdapat nilai kepuasan konsumen sebesar 10,525 point.

2) Koefisien regresi kualitas pelayanan sebesar 0,532 , angka ini positif artinya setiap ada peningkatan kualitas pelayanan sebesar 0,532 point maka kepuasan konsumen juga akan 
mengalami peningkatan sebesar 0,532 point.

\section{b. Analisis Koefisien Korelasi}

Analisis koefisien korelasi dimaksudkan untuk mengetahui tingkat kekuatan hubungan dari variabel independen terhadap variabel dependen. Adapun hasil pengujian sebagai berikut:

Tabel 3. Hasil Pengujian Koefisien Korelasi Kualitas pelayanan Terhadap Kepuasan konsumen. Correlations $^{\mathrm{b}}$

\begin{tabular}{llr|r} 
& & \multicolumn{1}{c}{$\begin{array}{c}\text { Kualitas } \\
\text { pelayanan }(X 1)\end{array}$} & \multicolumn{1}{c}{$\begin{array}{c}\text { Kepuasan } \\
\text { konsumen }(Y)\end{array}$} \\
\hline $\begin{array}{l}\text { Kualitas pelayanan } \\
(X)\end{array}$ & Pearson Correlation & 1 & $.651^{* *}$ \\
\cline { 2 - 4 } $\begin{array}{l}\text { Kepuasan konsumen } \\
(Y)\end{array}$ & Sig. (2-tailed) & .000 \\
\cline { 2 - 4 } & Pearson Correlation & $.651^{* *}$ & 1 \\
\hline
\end{tabular}

Berdasarkan hasil pengujian diperoleh nilai korelasi sebesar 0,651 artinya kualitas pelayanan memiliki hubungan yang kuat terhadap kepuasan konsumen.

\section{c. Analisis Koefisien Determinasi}

Analisis koefisien determinasi dimaksudkan untuk mengetahui besarnya persentase pengaruh dari variabel independen terhadap variabel dependen. Adapun hasil pengujian sebagai berikut:

Tabel 4. Hasil Pengujian Koefisien Determinasi Kualitas pelayanan Terhadap Kepuasan konsumen.

Model Summary

\begin{tabular}{lr|r|r|r} 
Model & R & R Square & Adjusted R Square & Std. Error of the Estimate \\
\hline 1 & $.651^{\mathrm{a}}$ & .424 & .416 & 2.188 \\
\hline
\end{tabular}

Berdasarkan hasil pengujian diperoleh nilai determinasi sebesar 0,424 artinya kualitas pelayanan memiliki kontribusi pengaruh sebesar $42,4 \%$ terhadap kepuasan konsumen, sedangkan sisanya sebesar $57,6 \%$ dipengaruhi oleh faktor lain yang tidak dilakukan penelitian.

Tabel 5. Hasil Uji Hipotesis Kualitas pelayanan Terhadap Kepuasan konsumen.

Coefficients $^{a}$

Unstandardized

Coefficients

\section{d. Uji Hipotesis}

Pengujian hipotesis dengan uji $t$ digunakan untuk mengetahui hipotesis mana yang diterima.

Rumusan hipotesis: Terdapat pengaruh yang signifikan kualitas pelayanan terhadap kepuasan konsumen.

\begin{tabular}{|c|c|c|c|c|c|}
\hline \multirow[b]{3}{*}{ Model } & \multicolumn{2}{|c|}{ Coefficients ${ }^{a}$} & \multirow[b]{2}{*}{$\begin{array}{l}\text { Standardized } \\
\text { Coefficients }\end{array}$} & \multirow[b]{3}{*}{$\mathrm{t}$} & \multirow[b]{3}{*}{ Sig. } \\
\hline & \multicolumn{2}{|c|}{$\begin{array}{l}\text { Unstandardized } \\
\text { Coefficients }\end{array}$} & & & \\
\hline & B & Std. Error & Beta & & \\
\hline 1 (Constant) & 10.525 & 2.197 & & 4.790 & .000 \\
\hline Kualitas pelayanan $(\mathrm{X})$ & .532 & .073 & .651 & 7.328 & .000 \\
\hline
\end{tabular}

Berdasarkan hasil pengujian pada tabel di atas, diperoleh nilai $\mathrm{t}$ hitung $>\mathrm{t}$ tabel atau $(7,328>1,996)$, dengan demikian hipotesis yang diajukan bahwa terdapat pengaruh yang signifikan atara kualitas pelayanan terhadap kepuasan konsumen diterima.

\section{PEMBAHASAN HASIL PENELITIAN}

1. Kondisi Jawaban Responden Variabel Kualitas pelayanan

Berdasarkan jawaban responden, variabel kualitas pelayanan diperoleh ratting score sebesar 3,007 berada di rentang skala 3,40 - 4,19 dengan kriteria baik atau setuju. 
2. Kondisi Jawaban Responden Variabel Kepuasan konsumen

Berdasarkan jawaban responden, variabel kepuasan konsumen diperoleh ratting score sebesar 2,652 berada di rentang skala 3,40 - 4,19 dengan kriteria baik atau setuju.

3. Pengaruh Kualitas pelayanan Terhadap Kepuasan konsumen

Kualitas pelayanan berpengaruh signifikan terhadap kepuasan konsumen dengan persamaan regresi $Y=10,525+$ $0,532 X$, nilai korelasi sebesar 0,651 atau memiliki hubungan yang kuat dengan kontribusi pengaruh sebesar $42,4 \%$. Pengujian hipotesis diperoleh nilai $\mathrm{t}$ hitung $>\mathrm{t}$ tabel atau $(7,328>1,996)$. Dengan demikian hipotesis yang diajukan bahwa terdapat berpengaruh signifikan antara kualitas pelayanan terhadap kepuasan konsumen diterima.

\section{PENUTUP}

\section{Kesimpulan}

a. Variabel kualitas pelayanan diperoleh ratting score sebesar 3,007 berada di rentang skala 3,40 - 4,19 dengan kriteria baik atau setuju.

b. Variabel kepuasan konsumen diperoleh ratting score sebesar 2,652 berada di rentang skala 3,40 - 4,19 dengan kriteria baik atau setuju.

c. Kualitas pelayanan berpengaruh signifikan terhadap kepuasan konsumen dengan persamaan regresi $Y=10,525+0,532 X$, nilai korelasi sebesar 0,651 atau kuat dan kontribusi pengaruh sebesar $42,4 \%$ sedangkan sisanya sebesar $57,6 \%$ dipengaruhi faktor lain. Uji hipotesis diperoleh nilai $\mathrm{t}$ hitung $>\mathrm{t}$ tabel atau $(7,328>$ 1,996).

\section{Saran}

Berdasarkan hasil penelitian di atas, maka penulis memberikan saran sebagai berikut:

a. Diharapkan kualitas pelayanan yang sudah baik terus dipertahankan dan ditingkatkan supaya konsumen bisa merasa puas. Perusahaan lebih menerima masukan dari konsumen sebagai bahan pertimbangan untuk mengembangkan lagi produknya sehingga pilihan yang tersedia pun semakin banyak dan beragam.

b. Perusahaan diharapkan bisa memberikan informasi yang jelas dan lebih menarik serta memperluas distribusinya agar konsumen bisa dengan mudah mendapatkan produk dan tempatnya pun harus cukup strategis atau mudah di jangkau oleh konsumen. Perusahaan harus lebih memperhatikan apa yang sedang diminati oleh konsumen sehingga bisa memenuhi kebutuhan konsumen yang berbeda-beda dan supaya konsumen bersedia untuk melakukan pembelian ulang dan tidak membeli di tempat lain.

\section{DAFTAR PUSTAKA}

Algifari. (2015). Analisis Regresi untuk Bisnis dan Ekonomi. Yogyakarta: BPFE.

Arikunto, Suharsimi (2014). Prosedur Penelitian Suatu Pendekatan Praktek. Jakarta: Rineka Cipta.

Bashu Swastha dan T. Handoko (2015) Manajemen Pemasaran Moderen, Yogyakarta: BPFE.

Basu Swastha Dharmmesta. (2014). Manajemen Pemasaran. BPFE:

Yogyakarta. Buchari Alma. 2014.

Manajemen Pemasaran dan

Pemasaran Jasa. Edisi Revisi.

Bilson Simamora (2016) Panduan Riset Prilaku Konsumen, Jakarta: PT. Gramedia Pustaka.

Erlangga, H., et al. (2021). Pengaruh Kualitas Pelayanan Dan Kualitas Produk Terhadap Keputusan Pembelian Konsumen Sepeda Motor Honda Di PT Panca Sakti Perkasa Di Bintaro. Jurnal Ilmiah PERKUSI, 1(4), 464-472.

Fandy Tjiptono (2017), Serivce Quality and Satisfiation. Jakarta: Edisi tiga. Andi.

Freddy Rangkuti (2016) Strategi Promosi Yang Kreatif, Edisi Pertama, Cetakan Pertama Jakarta: Gramedia Pustaka 
Utama.

Imam Ghozali (2017). Aplikasi Analisis Multivariate Dengan Program SPSS. Edisi Kelima. Semarang: Badan Penerbit Undip.

Istijanto (2014). Riset Sumber Daya Manusia. Jakarta: PT. Gramedia Pustaka

Kharis, Ismu Fadli (2011). Studi Mengenai Impulse Buying dalam Penjualan Online. Semarang : Skripsi Universitas Diponegoro

Kotler dan Amstrong (2017), Prinsip-prinsip Pemasaran. Edisi Kedua Belas". Jilid Satu. Jakarta: Erlangga.

Lupiyoadi (2016) Manajemen Pemasaran Jasa, Edisi 4, Jakarta: Salemba Empat.

Nurjaya, N., et al. (2021). Pengaruh Brand Image Terhadap Keputusan Pembelian Pada PT. Wahana Motor
Di Wilayah Cianjur. Jurnal Ilmiah PERKUSI, 1(2), 291-296.

Philip Kotler (2017) Manajemen Pemasaran, Edisi Keempat Belas, Jakarta: PT. Indeks.

Phipil Kotler dan Kevin Keller (2017) Manajemen Pemasaran, Edisi Kedua Belas, Jilid Satu, Jakarta: Erlangga.

Rao, Purba, (2012). Measuring Consumer Perceptions Through Factor Analysis. The Asian.

Santoso, Singgih (2015). Menguasai Statistik Multivariat. Jakarta: PT Elex Media Komputindo.

Sudjana (2014). Metode Statistika, Bandung: Tarsido.

Sugiyono (2017). Metode Penelitian Administrasi: dilengkapi dengan Metode $R \mathcal{E} D$. Bandung: Alfabeta. 